\title{
A Woodland Period Ceramic Assemblage from Rabbit Creek in the Sabine River Basin, Gregg County, Texas
}

Timothy K. Perttula

Heritage Research Center, Stephen F. Austin State University

Follow this and additional works at: https://scholarworks.sfasu.edu/ita

Part of the American Material Culture Commons, Archaeological Anthropology Commons, Environmental Studies Commons, Other American Studies Commons, Other Arts and Humanities Commons, Other History of Art, Architecture, and Archaeology Commons, and the United States History Commons

Tell us how this article helped you.

This Article is brought to you for free and open access by the Center for Regional Heritage Research at SFA ScholarWorks. It has been accepted for inclusion in Index of Texas Archaeology: Open Access Gray Literature from the Lone Star State by an authorized editor of SFA ScholarWorks. For more information, please contact cdsscholarworks@sfasu.edu. 


\section{A Woodland Period Ceramic Assemblage from Rabbit Creek in the Sabine River Basin, Gregg County, Texas}

\section{Creative Commons License}

\section{(c) (1) \&}

This work is licensed under a Creative Commons Attribution-NonCommercial 4.0 International License 


\section{A Woodland Period Ceramic Assemblage from Rabbit Creek in the Sabine River Basin, Gregg County, Texas}

\section{Timothy K. Perttula}

\section{INTRODUCTION}

The GC-123 site was located and investigated by Buddy C. Jones during his years of archaeological work and surface collecting at numerous aboriginal sites in the mid-Sabine River basin in East Texas. The site is in south-central Gregg County (Figure 1), on Rabbit Creek (a northern-flowing tributary to the Sabine River), but only a few miles from the Sabine River valley.

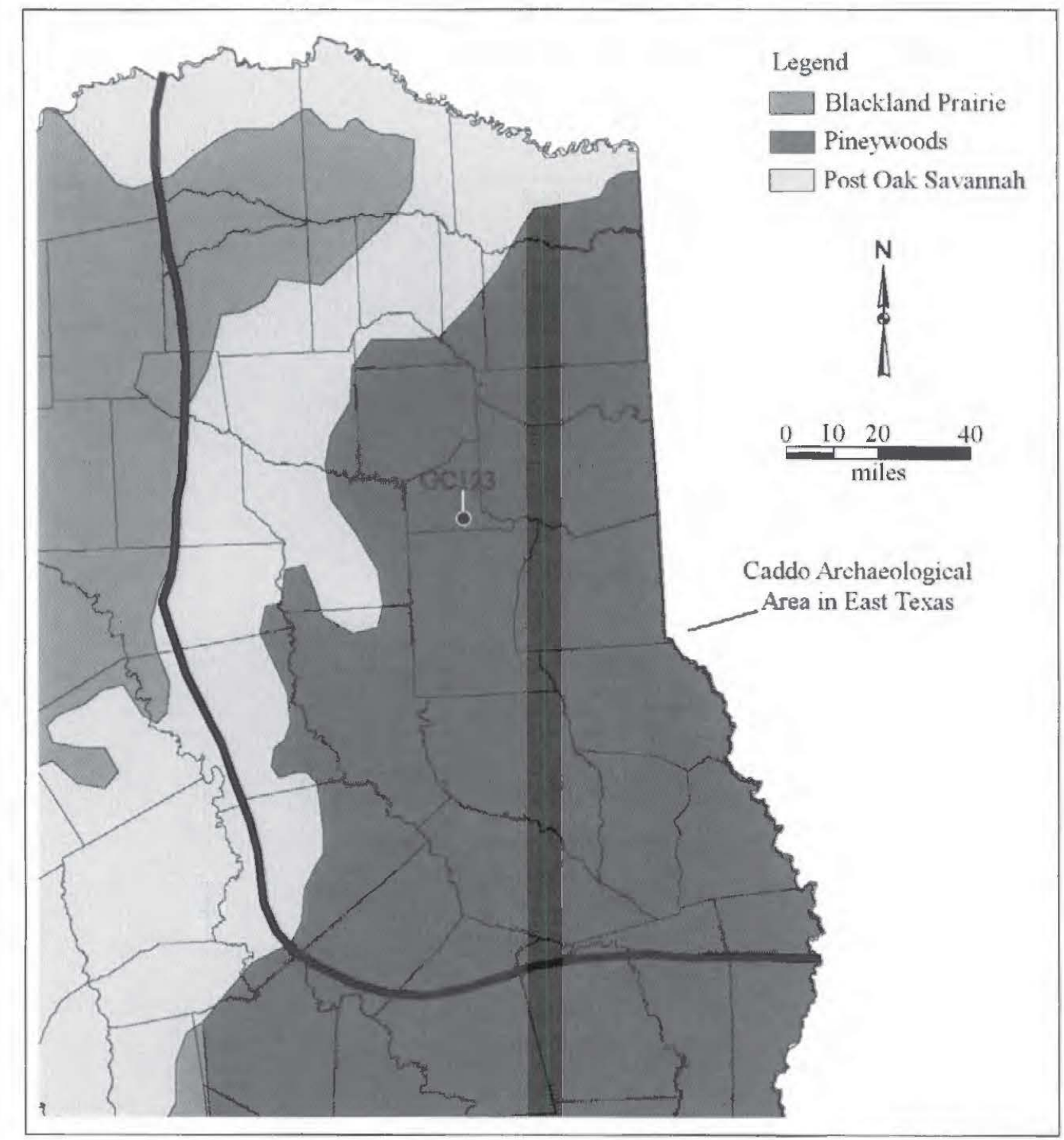

Figure 1. The location of Site GC-123 in East Texas. Figure prepared by Lance Trask. 
The site is notable for its ceramic sherd assemblage. Based on characteristics of Woodland period ceramics from the mid-Sabine River basin, including sites such as 41HS231 and 41RK562 (see Dockall and Fields 2011; Dockall et al. 2008), Hawkwind (41HS915), Folly (41RK26), Herman Ballew (41RK222), and Resch (41HS16 (see Ellis 2013; Ellis et al. 2013; Perttula 2001; Webb et al. 1969), the GC-123 site appears to be a single component Woodland period occupation.

\section{SHERD ASSEMBLAGE}

There are only 26 rim, body, and base sherds in the GC-123 assemblage. None of the sherds are decorated. About $73 \%$ of the sherds (four rims, 12 body, and three base) are from grog-tempered vessels, and the remaining $27 \%$ (seven body sherds) are bone-tempered.

The grog-tempered sherds are from plain bowls and jars with direct rims and rounded lips (Figure 2), with two different sizes: one group of rims with thin vessel walls (mean thickness of $6.0 \mathrm{~mm}$ ) and another with thick vessel walls (mean thickness of $11.1 \mathrm{~mm}$ ). The latter rim sherds may be from Williams Plain vessels. Grog-tempered body sherds are variable in thickness, with a range from $6.1-10.0 \mathrm{~mm}$, with a mean thickness of $7.66 \mathrm{~mm}$. Grog-tempered base sherds have a mean thickness of $11.67 \mathrm{~mm}$. The thickness of the plain grog-tempered vessels at GC-123 is comparable to the vessels from the Woodland period components at the Hawkwind and Resch sites (Ellis 2013:151).

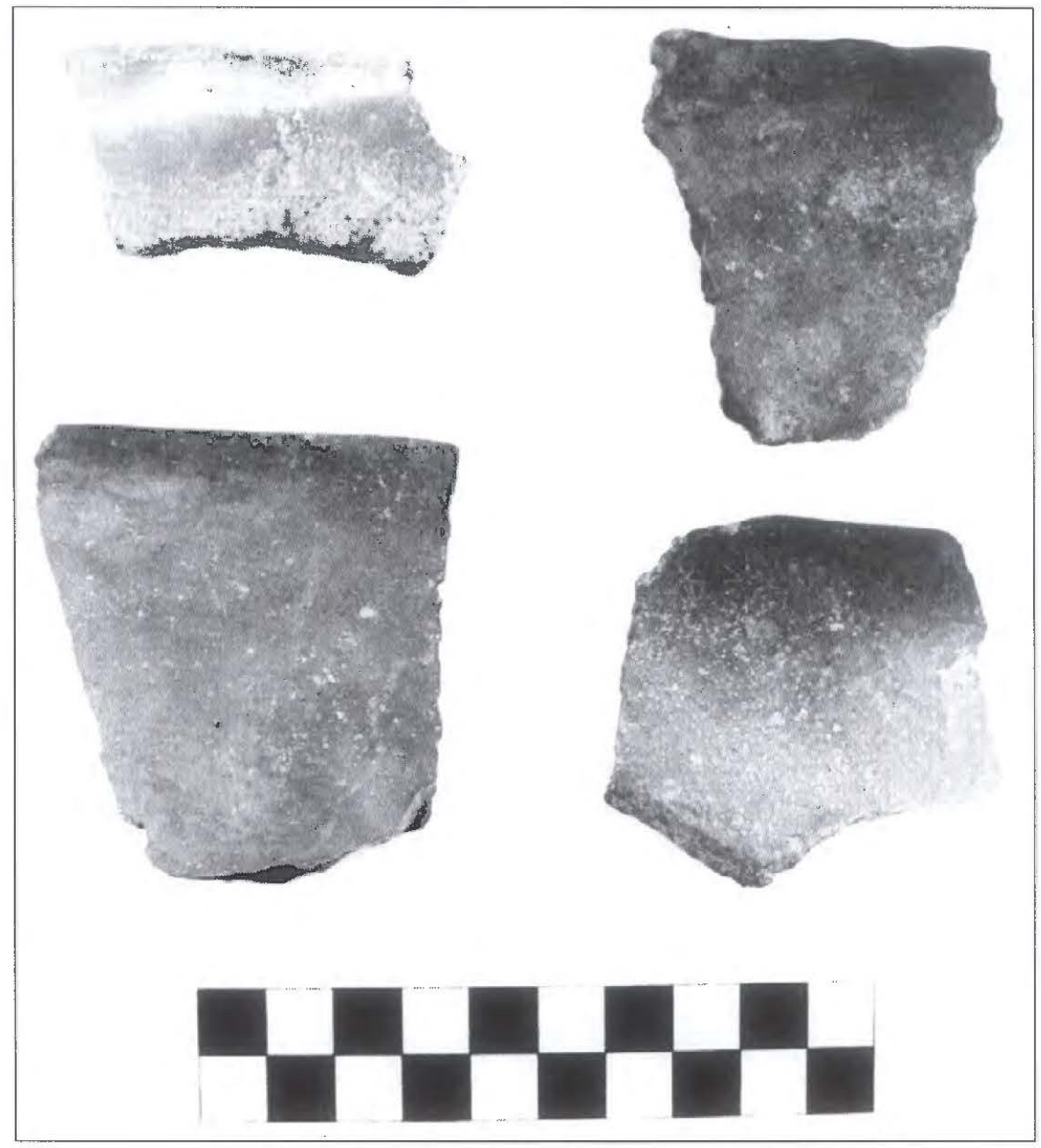

Figure 2. Plain grog-tempered rim sherds from site GC-123. 
The bone-tempered sherds are from thick and coarsely tempered vessels, as the mean thickness of the body sherds is $9.87 \mathrm{~mm}$, with a range from $5.0-11.2 \mathrm{~mm}$. These are likely sherds from Cooper Boneware jars (cf. Schambach 1998).

\section{SUMMARY AND CONCLUSIONS}

The small sample ( $\mathrm{n}=26$ ) of plain ware sherds from site $\mathrm{GC}-123$ in the mid-Sabinc River basin are from thin and thick-walled grog-tempered and thick-walled bone-tempered vessels, likely including both Williams Plain and Cooper Boneware. The sherds appear to be from a single component Woodland period occupation. The occurrence of Cooper Boneware sherds at GC-123 suggests that the Woodland period occupation took place sometime prior to ca. A.D. 400 (e.g., Ellis 2013:173).

\section{REFERENCES CITED}

Dockall, J. E. and R. C. Fields

2011 National Register Testing of Three Sites in the Sabine Mine's South Hallsville No. I Mine-Rusk Permit, Rusk County, Texas. Report of Investigations No. 162. Prewitt and Associates, Inc., Austin.

Dockall, J., S. Katauskas, and R. Fields

2008 National Register Testing of Four Sites in the Sabine Mine's Area M, Harrison County, Texas. Reports of Investigations No. 157. Prewitt and Associates, Inc., Austin.

Ellis, L. W.

2013 Woodland Ceramics in East Texas and a Case Study of Mill Creek Culture Ceramics. Bulletin of the Texas Archeological Society 84:137-180.

Ellis, L. W., R. Rogers, C. Wallace, D. Burden, A. Burden, A. Kalter, M. Smith, and C. Heiligenstein

2013 Data Recovery at the Hawkwind Site (4IHSY15), Harrison County, Texas. Document No. 120087. Atkins, and Report No. 138, Archeological Studies Program, Environmental Affairs Division, Texas Department of Transportation, Austin.

Perttula, T. K.

2001 Ceramic Analysis. In Excavations at the Herman Bellew Site (4/RK222), Rusk County, Texas, by R. M. Rogers, M. A. Nash, and T. K. Perttula, pp. 98-130. Document No. 000021. PBS\&J. Inc., Austin.

Schambach, F. F.

1998 Pre-Caddoan Cultures of the Trans-Mississippi South. Research Series 53. Arkansas Archeological Survey, Fayetteville.

Webb, C. H., F. E. Murphey, W. G. Ellis, and H. R. Green

1969 The Resch Site, 41HS16, Harrison County, Texas. Bulletin of the Texas Archeological Society 40:3-106. 